\title{
Antimalarial Activity of Crambescidin 800 and Synthetic Analogues against Liver and Blood Stage of Plasmodium sp.
}

\author{
J. Enrico H. Lazaro, Josiane Nitcheu, Nassira Mahmoudi, Joyce A. Ibana, Gina C. Mangalindan, \\ Gregory P. Black, Andrew G. Howard-Jones, Christopher G. Moore, Dafydd A. Thomas, \\ Dominique Mazier, Chris M. Ireland, Gisela P. Concepcion, Patrick J. Murphy, \\ Bertrand Diquet ${ }^{\dagger}$
}

This article is dedicated to the memory of the late Prof. Kenneth L. Rinehart who first worked on crambescidin.

Received: April 26, 2006 / Accepted: September 7, 2006

(C) Japan Antibiotics Research Association

\begin{abstract}
Structural features associated with the antimalarial activity of the marine natural product crambescidin 800 were studied using synthetic analogues of the related compound ptilomycalin A. The study suggests that the guanidine moiety is cytotoxic, whereas the spermidine-containing aliphatic chain increases activity. The most active analogue, compound 11, had in vitro activity against Plasmodium falciparum strain 3D7 $\left(\mathrm{IC}_{50}=490 \mathrm{nM}\right)$ that was stronger than the in vitro activity against murine $\mathrm{L} 5178 \mathrm{Y}$ cells $\left(\mathrm{IC}_{50}=8.5 \sim 59 \mu \mathrm{M}\right)$. In vitro growth inhibition of liver stages of $P$. yoelii yoelii in mouse hepatocytes was observed $\left(\mathrm{IC}_{50}=9.2 \mu \mathrm{M}\right)$. The compound did not significantly prolong median survival time after a single subcutaneous administration of $80 \mathrm{mg} / \mathrm{kg}$ in $P$. berghei-infected mice. Compound $\mathbf{1 1}$ did not cause DNA fragmentation in an in vitro micronucleus assay.
\end{abstract}

Keywords malaria, natural product, crambescidin, Plasmodium

\section{Description}

Crambescidin 800 was isolated from a Mycophora sp. sponge. The methanol extract was partitioned with hexane, dichloromethane (DCM) and chloroform. The DCM fraction was chromatographed successively on Sephadex LH20 $(101.6 \times 2.5 \mathrm{~cm}, 100 \%$ methanol, $2 \mathrm{ml} /$ minute, elution volume $\left(\mathrm{V}_{\mathrm{e}}\right)=280 \mathrm{ml}$ ) and $\mathrm{C} 18$ columns (gravity column, $50.8 \times 2.5 \mathrm{~cm}$, methanol/water $9: 1,1 \mathrm{ml} /$ minute, $\mathrm{V}_{\mathrm{e}}=33 \mathrm{ml}$ ) yielding a bioactive fraction $(55.4 \mathrm{mg})$ whose ${ }^{1} \mathrm{H}$ - and ${ }^{13} \mathrm{C}$ NMR shifts and mass spectrum data matched previously reported values for crambescidin 800 [1].

Analogues had been synthesized as described and were provided (by P. J. Murphy) as pure crystalline solids [2 5]. The structures are shown in Fig. 1.

The structures of crambescidin 800, ptilomycalin A, and the synthetic compound $\mathbf{1 1}$ are shown in Fig. 2.
J. E. H. Lazaro (Corresponding author), J. A. Ibana, G. C. Mangalindan, G. P. Concepcion: Marine Science Institute, University of the Philippines, Diliman 1101, Quezon City, Philippines, E-mail: jlazaro@uap.edu.ph

J. Nitcheu, N. Mahmoudi, B. Diquet, D. Mazier: INSERM U511 Immuno-Biologie Cellulaire et Moléculaire des Infections Parasitaires, Centre Hospitalo-Universitaire Pitié-Salpêtrière, Université Pierre et Marie Curie, 75013 Paris, France
G. P. Black, A. G. Howard-Jones, C. G. Moore, D. A. Thomas: Department of Chemistry, University of Wales, Bangor, Gwynedd LL57 2UW, UK

C. M. Ireland: Department of Medicinal Chemistry, University of Utah, Salt Lake City, UT, USA

${ }^{\dagger}$ Present address: Service de Pharmacologie et de Toxicologie, Centre Hospitalier Universitaire, 49033 Angers, France 
<smiles>O=C1CCN2CCC(=O)NC2=N1</smiles><smiles>[R]C1CCC[C@]2(CCN3CC[C@]4(CCC[C@@H]([R])O4)NC3=N2)O1</smiles>

$5 ; \mathrm{R}^{\prime}=\mathrm{OSi}(t-\mathrm{Bu}) \mathrm{Ph}_{2}: \mathrm{X}=\mathrm{Br}$ $6 ; \mathrm{R}^{\prime}=\mathrm{Me}: \mathrm{X}=\mathrm{BF}_{4}$ $7 ; \mathrm{R}^{\prime}=\mathrm{CH}_{2} \mathrm{OH}: \mathrm{X}=\mathrm{Cl}$.<smiles>[R]C[C@@H](F)NC1=NC([R])C[C@H]2CC[C@H]([2H])N12</smiles><smiles>[H][R]([H])([H])[C@H]1CCCO[C@]12CCCCO2</smiles>

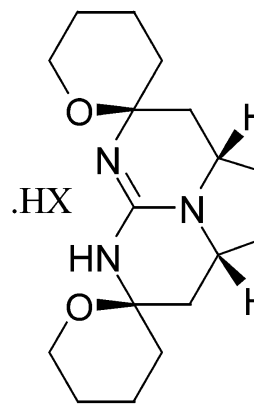

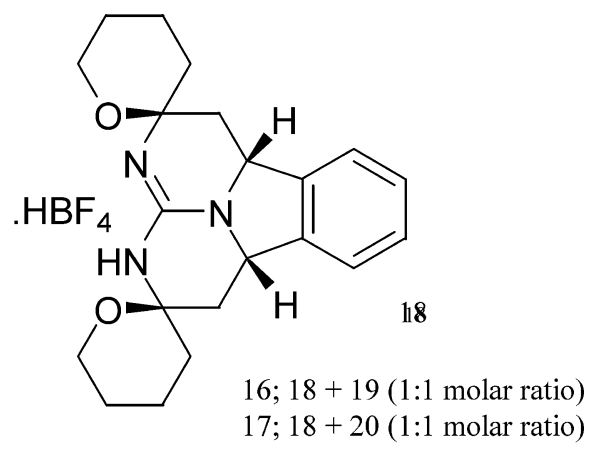

$12 ; \mathrm{R}^{\prime \prime}=\mathrm{CH}_{2} \mathrm{OH}$

$13 ; \mathrm{R}^{\prime \prime \prime}=\mathrm{CO}_{2} \mathrm{H}$

$14 ; \mathrm{R}^{\prime \prime \prime}=\mathbf{A}$

$15 ; \mathrm{R}^{\prime \prime \prime}=\mathbf{B}$.

$17 ; 18+20$ (1:1 molar ratio)

8; $\mathrm{R}^{\prime \prime}=\mathrm{CH}_{2} \mathrm{OH}: \mathrm{X}=\mathrm{Cl}$

9; $\mathrm{R}^{\prime \prime}=\mathrm{CO}_{2} \mathrm{H}: \mathrm{X}=\mathrm{BF}_{4}$

$10 ; R^{\prime \prime}=\mathbf{A}: \mathrm{X}=\mathrm{BF}_{4}$

$11 ; \mathrm{R}^{\prime \prime}=\mathbf{B}: \mathrm{X}=\mathrm{BF}_{4}$.<smiles>CCCCNCCCCN(CCCNC(=O)OCc1ccccc1)C(=O)OC</smiles><smiles>COC(=O)N(CCCN)CCCCN</smiles><smiles>CC(C)(C)OC(=O)NCCCCN(CCCNC(=O)OCc1ccccc1)C(=O)O</smiles><smiles>CC(=O)N(CCCN)CCCCN</smiles>

Fig. 1 Synthetic crambescidin analogues. 


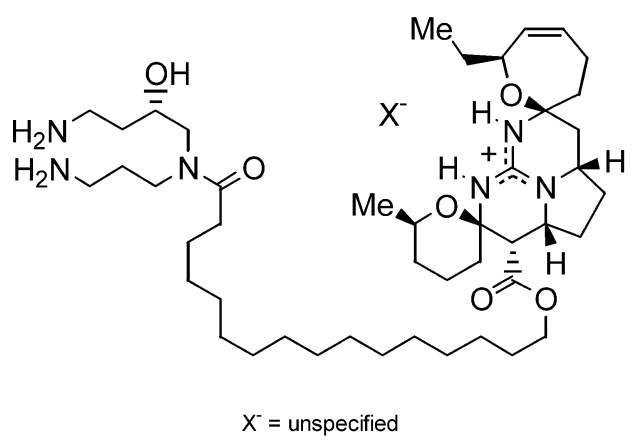

Crambescidin 800

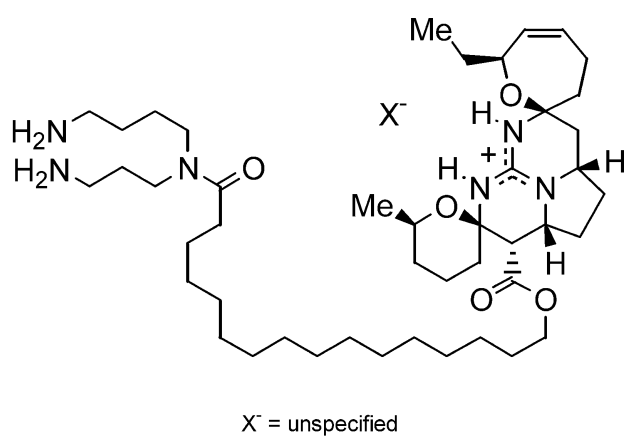

Ptilomycalin A

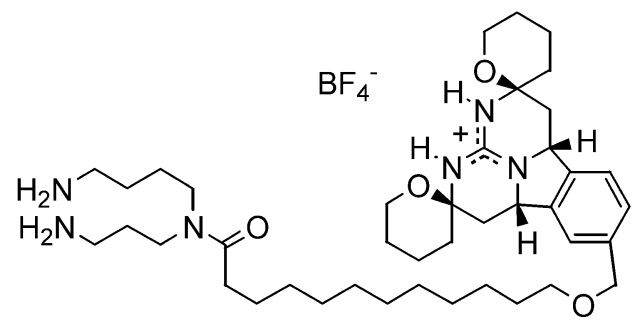

Compound 11

Fig. 2 Structures of crambescidin 800, ptilomycalin A, and the analogue compound 11.

Crambescidin LR-MS (pos-FAB): $801\left(\mathrm{MH}^{+}\right), \mathrm{C}_{45} \mathrm{H}_{81} \mathrm{~N}_{6} \mathrm{O}_{6}$.

\section{Antimalaria Assay against the Erythrocytic Stage of Plasmodium falciparum}

P. falciparum strains (chloroquine-sensitive $3 \mathrm{D} 7 \mathrm{w}$ and chloroquine-resistant FCR3) were maintained in culture as described [6]. Crambescidin 800 and synthetic analogues were tested against the parasites using the tritiated hypoxanthine assay for drug sensitivity [7]. Scintillation counts-per-minute (cpm) were adjusted relative to controls to obtain a \%inhibition, $\mathrm{p}$, which was transformed using the arcsine transformation, $\mathrm{p}^{\prime}=\arcsin \sqrt{\mathrm{p}}$, as described [8]. The $\mathrm{IC}_{50}$ was then estimated by linear regression of $\mathrm{p}^{\prime}$ versus $\log \mathrm{nM}$ of compound. The significance of the differences between the curves defined by these data points was tested by a two-factor ANOVA using Statview ${ }^{\circledR}$ (SAS Institute, USA). The F statistic was used, with $\alpha=0.05$.

Crambescidin 800 showed in vitro activity against FCR3 $\left(\mathrm{IC}_{50}=240 \mathrm{nM}, \mathrm{CI} 140 \sim 340 \mathrm{nM}\right)$ and $3 \mathrm{D} 7\left(\mathrm{IC}_{50}=160 \mathrm{nM}\right.$, CI $100 \sim 230 \mathrm{nM}$ ). This activity is comparable to quinine $\left(\mathrm{IC}_{50}=290 \mathrm{nM}, \mathrm{CI} 200 \sim 350 \mathrm{nM}\right)$. The in vitro $\mathrm{IC}_{50}$ 's of the synthetic analogues against chloroquine-sensitive strain 3D7 are given in Table 1.

Compound $\mathbf{1 1}$ was the most active synthetic analogue. Its in vitro antimalarial activity was comparable to quinine and slightly less than that of crambescidin 800 .

\section{Antimalaria in Vivo Assay}

C57BL/6N mice (age 6 weeks, Charles River, France) were inoculated intraperitoneally with $1 \times 10^{6} \mathrm{P}$. berghei (Clone 1.49L of ANKA strain, a kind gift of Dr. D. Walliker, Institute of Genetics, Edinburgh, UK) parasites (day 0). Compound 11 and quinine were dissolved in peanut oil containing $10 \% \mathrm{DMSO}$, at a concentration of 20 and $10 \mathrm{mg} / \mathrm{kg}$, respectively. A single subcutaneous dose of $80 \mathrm{mg} / \mathrm{kg}$ of compound 11 and $40 \mathrm{mg} / \mathrm{kg}$ of quinine (a high non-toxic dose according to Schneider [9]) were administered on day 3 after infection. Negative control was $10 \%$ DMSO in peanut oil. Positive control was a subcutaneous administration on day 3 with $20 \mathrm{mg} / \mathrm{kg}$ of heptyl prodigiosin in peanut oil [10]. There were eight (8) mice per group. Parasitemia was counted daily using thin smear and Giemsa staining.

Survival curves were determined with the method of Kaplan-Meier using Statview ${ }^{\circledR}$. The Mantel-Cox log rank test was used to evaluate the chi-square and $p$ values of the curves with $\alpha=0.05$. Parasite counts were compared with the solvent control group using the $\chi^{2}$ test with $\alpha=0.05$.

Compound $11(80 \mathrm{mg} / \mathrm{kg})$ and quinine $(40 \mathrm{mg} / \mathrm{kg}) \mathrm{did}$ not retard the rise in parasitemia, nor did they increase the median survival time. However, the parasitemia in mice 
Table 1 Antimalarial activity of ptilomycalin A analogues against chloroquine-sensitive of blood stage (3D7 clone) of $P$. falciparum

\begin{tabular}{|c|c|c|c|}
\hline Compound & Formula & Mol wt & $\mathrm{IC}_{50}$, average and $95 \% \mathrm{Cl}(\mathrm{nM})$ \\
\hline 1 & $\mathrm{C}_{7} \mathrm{H}_{9} \mathrm{O}_{2} \mathrm{~N}_{3} \cdot \mathrm{HCl}$ & 203.628 & $>50000$ \\
\hline 2 & $\mathrm{C}_{21} \mathrm{H}_{23} \mathrm{~N}_{3} \cdot \mathrm{HBF}_{4}$ & 405.245 & $>25000$ \\
\hline 3 & $\mathrm{C}_{17} \mathrm{H}_{27} \mathrm{O}_{2} \mathrm{~N}_{3} \cdot \mathrm{HBF}_{4}$ & 393.230 & $>25000$ \\
\hline 4 & $\mathrm{C}_{27} \mathrm{H}_{51} \mathrm{~N}_{3} \cdot \mathrm{HBF}_{4}$ & 505.532 & $4300(3400 \sim 5500)$ \\
\hline 5 & $\mathrm{C}_{17} \mathrm{H}_{27} \mathrm{O}_{2} \mathrm{~N}_{3}(\mathrm{OTBDPS})_{2} \cdot \mathrm{HBr}$ & 897.153 & $850(490 \sim 1200)$ \\
\hline 6 & $\mathrm{C}_{17} \mathrm{H}_{29} \mathrm{O}_{2} \mathrm{~N}_{3} \cdot \mathrm{HBF}_{4}$ & 395.246 & $6200(3300 \sim 16000)$ \\
\hline 7 & $\mathrm{C}_{17} \mathrm{H}_{29} \mathrm{O}_{4} \mathrm{~N}_{3} \cdot \mathrm{HCl}$ & 375.894 & $>25000$ \\
\hline 8 & $\mathrm{C}_{34} \mathrm{H}_{54} \mathrm{O}_{4} \mathrm{~N}_{3} \mathrm{Cl}$ & 604.271 & $740(510 \sim 1000)$ \\
\hline 9 & $\mathrm{C}_{34} \mathrm{H}_{52} \mathrm{O}_{5} \mathrm{~N}_{3} \mathrm{BF}_{4}$ & 669.604 & $>15000$ \\
\hline 10 & $\mathrm{C}_{41} \mathrm{H}_{67} \mathrm{O}_{4} \mathrm{~N}_{6}(\mathrm{Boc})_{2} \mathrm{BF}_{4}$ & 997.070 & $2800(2400 \sim 3600)$ \\
\hline 11 & $\mathrm{C}_{41} \mathrm{H}_{69} \mathrm{O}_{4} \mathrm{~N}_{6} \mathrm{BF}_{4} \cdot 2 \mathrm{HCl}$ & 869.759 & $490(300 \sim 730)$ \\
\hline 12 & $\mathrm{C}_{27} \mathrm{H}_{40} \mathrm{O}_{4} \mathrm{~N}_{3} \mathrm{BF}_{4}$ & 557.433 & $3700(3000 \sim 4700)$ \\
\hline 13 & $\mathrm{C}_{27} \mathrm{H}_{38} \mathrm{O}_{5} \mathrm{~N}_{3} \mathrm{BF}_{4}$ & 571.416 & $>18000$ \\
\hline 14 & $\mathrm{C}_{34} \mathrm{H}_{53} \mathrm{O}_{4} \mathrm{~N}_{6}(\mathrm{Boc})_{2} \mathrm{BF}_{4}$ & 898.882 & $5700(5300 \sim 6100)$ \\
\hline 15 & $\mathrm{C}_{34} \mathrm{H}_{55} \mathrm{O}_{4} \mathrm{~N}_{6} \mathrm{BF}_{4} \cdot 2 \mathrm{HCl}$ & 771.571 & $>13000$ \\
\hline 16 & $\mathrm{C}_{21} \mathrm{H}_{28} \mathrm{O}_{2} \mathrm{~N}_{3} \mathrm{BF}_{4}+\mathrm{C}_{19} \mathrm{H}_{39} \mathrm{ON}_{3}(\mathrm{Boc})_{2}$ & 969.060 & $3200(2400 \sim 4600)$ \\
\hline 17 & $\mathrm{C}_{21} \mathrm{H}_{28} \mathrm{O}_{2} \mathrm{~N}_{3} \mathrm{BF}_{4}+\mathrm{C}_{19} \mathrm{H}_{41} \mathrm{ON}_{3} 2 \mathrm{HCl}$ & 841.749 & $2100(1400 \sim 2900)$ \\
\hline 18 & $\mathrm{C}_{21} \mathrm{H}_{28} \mathrm{O}_{2} \mathrm{~N}_{3} \mathrm{BF}_{4}$ & 441.274 & $2300(1800 \sim 3300)$ \\
\hline 19 & $\mathrm{C}_{19} \mathrm{H}_{39} \mathrm{ON}_{3}(\mathrm{Boc})_{2}$ & 527.785 & $>19000$ \\
\hline 20 & $\mathrm{C}_{19} \mathrm{H}_{41} \mathrm{ON}_{3}$ & 311.554 & $>10000$ \\
\hline
\end{tabular}

Notes:

1. OTBDPS, $\left(\mathrm{CH}_{3}\right)_{3} \mathrm{CSi}\left(\mathrm{C}_{6} \mathrm{H}_{5}\right)_{2} \mathrm{O}$

2. Boc, tert-oxybutylcarbonyl, $\mathrm{C}\left(\mathrm{CH}_{3}\right)_{3} \mathrm{OCO}-$

3. Strain $3 D 7$ is chloroquine-sensitive.

4. $I C_{50}$ of chloroquine was $12 \sim 50 \mathrm{nM}$, within the expected range for this strain.

treated with $\mathbf{1 1}$ was lower relative to the solvent control group on days $4(\mathrm{p}=0.004), 5(\mathrm{p}<0.001)$, and $6(\mathrm{p}=0.008)$. The parasitemias were no longer different on day 7 . As for quinine, there was almost a significant difference in parasitemia on day $4(\mathrm{p}=0.064)$ and a significant difference on day $5(\mathrm{p}=0.002)$. Parasitemias between the quinine and solvent groups were similar thereafter. There was no significant difference between the parasitemias in the quinine and compound $\mathbf{1 1}$ groups on all days scored.

In contrast, the antimalarial compound heptyl prodigiosin $(20 \mathrm{mg} / \mathrm{kg}$ ) retarded parasitemia until day 12 and significantly increased survival time (Fig. 3). (All surviving mice were allowed to eventually die of anemia.)

\section{In Vitro Drug Susceptibility Assays on Hepatic Stages of Plasmodium yoelii yoelii}

The in vitro activities of the compounds against hepatic stages were examined using $P$. yoelii yoelii cultured in mouse hepatocytes.

Hepatocytes were collected from the liver of autopsied

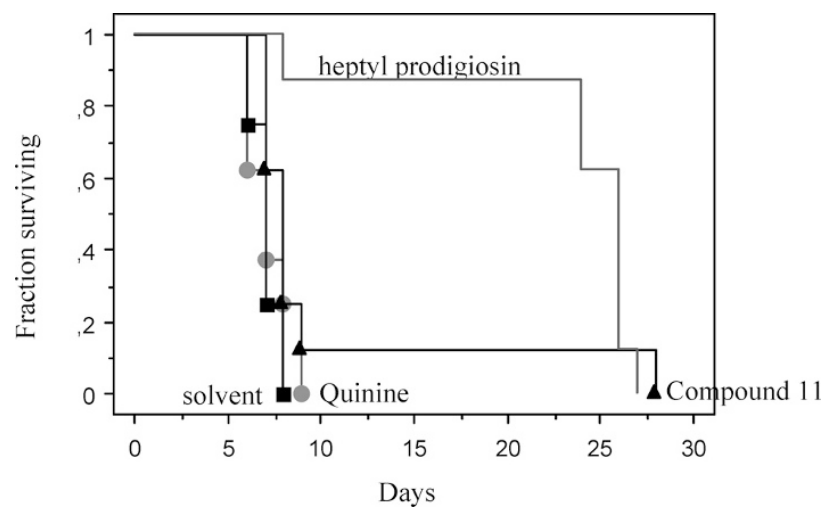

Fig. 3 Kaplan-Meier survival curves of compound $\mathbf{1 1}$ $(80 \mathrm{mg} / \mathrm{kg})$, quinine $(40 \mathrm{mg} / \mathrm{kg})$, and solvent $(80 \mu \mathrm{l}$ of $10 \%$ DMSO in peanut oil), and antimalarial compound heptyl prodigiosin $(20 \mathrm{mg} / \mathrm{kg})$.

Drugs and solvent were administered subcutaneously on day 3 after infection. Number of mice per group $=8$. Mantel-Cox logrank $\chi^{2}=3.361, p=0.1863$. 


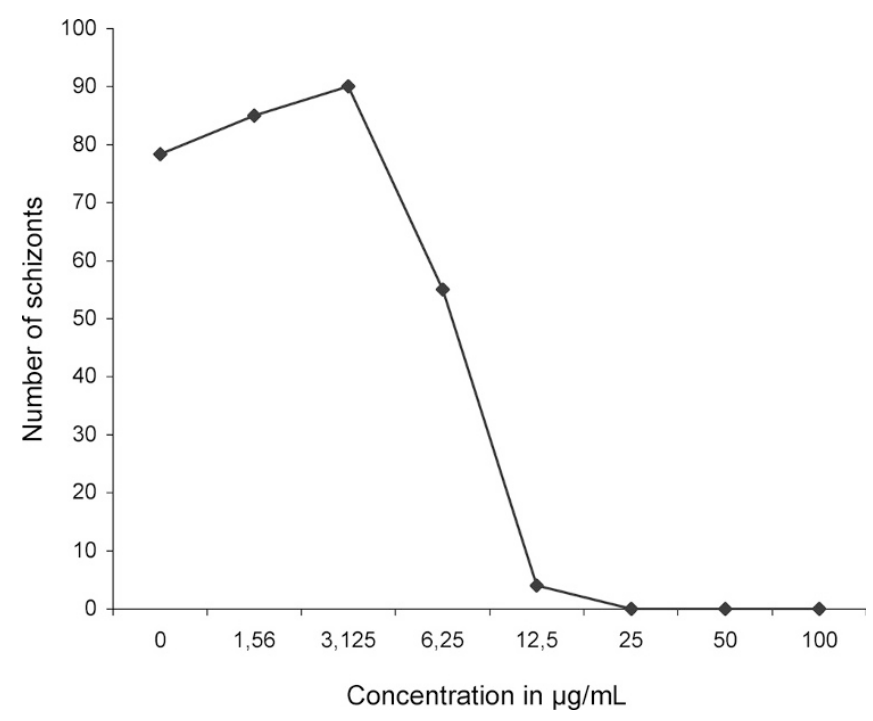

Fig. 4 Activity of compound $\mathbf{1 1}$ on hepatic stages of $P$. yoelii yoelii grown in cultured mouse hepatocytes.

Concentrations are given on a semi-logarithmic scale. $\mathrm{IC}_{50}=8 \mu \mathrm{g} / \mathrm{ml}$, or $9.2 \mu \mathrm{M}$.

8 16 week old Swiss mice (Charles Rivers, Orleans, France). They were isolated from the tissues by collagenase perfusion as previously described $[11,12]$ then resuspended in William's medium (Gibco, Cergy-Pontoise, France) supplemented to a final concentration of $10 \%$ fetal calf serum (Gibco), 2\% penicillin - streptomycin, 1\% sodium pyruvate, $1 \% \mathrm{~L}$-glutamine, $1 \%$ insulin - transferrin - selenium, at $37^{\circ} \mathrm{C}$ in $4 \% \mathrm{CO}_{2}$. Eighty thousand mouse hepatocytes were seeded in each well allowing cell confluence. Cultures were incubated at $37^{\circ} \mathrm{C}, 4 \% \mathrm{CO}_{2}$ and $96 \%$ air for 24 hours before sporozoite inoculation.

Sporozoites were obtained by dissection of the salivary glands of Anopheles stephensi mosquitos infected with $P$. yoelii yoelii (265 BY strain). Sporozoites were suspended in complete William's culture medium and kept chilled until counted in a Malassez chamber.

About $8 \times 10^{4}$ sporozoites were applied to each well of mouse hepatocyte cultures. Seven concentrations were tested, ranging between 1 and $100 \mathrm{mg} /$ liter. After 3 hours the culture medium was removed and replaced by fresh medium containing the drug at the selected concentration. Incubation proceeded for 48 hours.

Slides were then fixed in cold methanol for 10 minutes, then incubated for 1 hour at $37^{\circ} \mathrm{C}$ with a polyclonal antibody directed against the heat shock protein of Plasmodium (HSPi72) at a dilution of $1 / 500$ [11, 12]. The slides were then washed in phosphate-buffered saline (PBS) and incubated for 1 hour at $37^{\circ} \mathrm{C}$ with a solution containing an anti-mouse IgG FITC conjugate (Sigma) diluted at
Table 2 Size of schizonts in the treated cultures compared with untreated cultures

\begin{tabular}{ccc}
\hline Compounds & Size $(\mu \mathrm{M})$ & $\mathrm{p}$ \\
\hline Control & $19.5 \pm 8.57$ & \\
Compound $\mathbf{1 1}$ & & $<0.0001$ \\
$6.125 \mu \mathrm{g} / \mathrm{ml}$ & $3.57 \pm 0.1$ & $\mathrm{NS}$ \\
$12.5 \mu \mathrm{g} / \mathrm{ml}$ & $14.8 \pm 6.54$ & \\
\hline
\end{tabular}

Table 3 Antimalarial activity of synthetic analogues against hepatic stages of $P$. yoelii yoelii at 48 hours

\begin{tabular}{ccc}
\hline & $\begin{array}{c}\text { Activity against hepatic } \\
\text { stages of } P \text {. yoelii yoelii }\end{array}$ & \multicolumn{1}{c}{$\begin{array}{c}\text { Effect on } \\
\text { schizont size }\end{array}$} \\
\cline { 2 - 3 } & $\mathrm{IC}_{50}(\mu \mathrm{g} / \mathrm{ml})^{\mathrm{a}}$ & \\
\hline $\mathbf{1}$ & $>100$ & No \\
$\mathbf{3}$ & 38.02 & No \\
$\mathbf{6}$ & $>100$ & No \\
$\mathbf{8}$ & 63.81 & No \\
$\mathbf{1 0}$ & $>100$ & No \\
$\mathbf{1 1}$ & 8.02 & Yes \\
$\mathbf{1 2}$ & 67.8 & No \\
$\mathbf{1 5}$ & $>100$ & No \\
\hline
\end{tabular}

${ }^{a}{ } C_{50}$ were calculated from the average number of schizonts in four replicate wells for 9 concentrations of each drug comparatively to controls.

1/500, with 4',6-diamidino-2-phenyindole (DAPI) (Sigma) diluted at 1/1000 and Evans Blue (Sigma) at 1/150000. The slides were then mounted with PBS-glycerol $(50: 50$, $\mathrm{vol} / \mathrm{vol}$ ) and the schizonts were examined at $250 \times$ magnification. The number and size of schizonts in the cultures were noted. For the hepatic stage, the $\mathrm{IC}_{50}$ of each compound was determined from the schizont counts calculated from four replicate cultures [12].

Compound $\mathbf{1 1}$ reduced the number of hepatic schizonts, with an $\mathrm{IC}_{50}$ of $8 \mu \mathrm{g} / \mathrm{ml}$ or $9.2 \mu \mathrm{M}$ (Fig. 4). This observation was associated with marked alteration of schizont morphology without alteration of hepatocytes (data not shown). A significant reduction of the mean schizont size was also noted compared to controls (Table 2). Staining with DAPI showed that treated schizonts contained much less nuclear material than control (data not shown).

Compounds $1,3,6,8,10,12$, and 15 were also tested, but inhibitory effects on the maturation of hepatic stages were moderate (Table 3 ). 
Table 4 Results of the L5178Y in vitro micronucleus assay of compound $\mathbf{1 1}$ with S9 activation. The compound is not genotoxic according to this test

\begin{tabular}{lccccc}
\hline Product & Dose $\mu \mathrm{g} / \mathrm{ml}$ & $\begin{array}{c}\text { \%Survival based on } \\
\text { MTT assay }\end{array}$ & $\begin{array}{c}\text { Micronucleated } \\
\text { lymphocytes } \\
\text { per } 2000 \text { cells }\end{array}$ & $\chi^{2}$ & $p$ \\
\hline DMSO & 0 & 100 & 3 & 71.913 & $<0.001$ \\
Cyclophosphamide & 10 & 101.6 & 79 & 0 & N.S. \\
Compound $\mathbf{1 1}$ & 50.0 & 60.6 & 4 & 0.167 & N.S. \\
& 25.0 & 103.5 & 3 & 0 & N.S. \\
\hline
\end{tabular}

\section{Micronucleus Assay}

A microscale version of the in vitro rodent micronucleus assay for DNA fragmentation activity was used as described [13]. Briefly, cells were treated with drug, with or without S9 liver microsomes (S9 mix). Compound $\mathbf{1 1}$ was dissolved in DMSO at a concentration of $10 \mathrm{mg} / \mathrm{ml}$, diluted to $1000 \mu \mathrm{g} / \mathrm{ml}$ and then for 10 successive 2-fold dilutions thereafter with Fisher's medium (with 10\% decomplemented horse serum, or FM10; Gibco BRL, Paisley, UK) with or without $10 \%$ S9 mix. Contents were then dispensed $(100 \mu \mathrm{l})$ into 96-well plates (Costar, Brumath, France). Mouse lymphoma L5178Y (TK +/- clone 3.7.2C, Porton Down, Salisbury, UK) in $100 \mu 1$ of culture were added to all wells $(600,000$ cells $/ \mathrm{ml}$ for S9 treatment; 650,000 cells $/ \mathrm{ml}$ for no S9 and 24 hours incubation; 400,000 cells $/ \mathrm{ml}$ for no S9 and 24 hours incubation plus a 20 -hour recovery period).

Cells treated without S9 were cultured with drug for 24 hours $\left(37^{\circ} \mathrm{C}, 5 \% \mathrm{CO}_{2}, 100 \%\right.$ humidity). They were then either washed and incubated for a further 20 hours (recovery period) without drug, or harvested immediately. Cells treated in the presence of S9 were cultured for 4 hours with drug, washed to remove S9 and drug, incubated for a further 20 hours, then harvested. Positive controls were cyclophosphamide $(10 \mu \mathrm{g} / \mathrm{ml}$ final concentration in wells) for treatment with $\mathrm{S} 9$, and mitomycin C $(0.05 \mu \mathrm{g} / \mathrm{ml}$ without recovery period or $0.025 \mu \mathrm{g} / \mathrm{ml}$ with a 20 -hour recovery period) for treatment without $\mathrm{S} 9$. Negative control was $1 \%$ DMSO in culture medium.

Treatments were done in duplicate and coupled to a test for cytotoxicity (see below). Harvested cells were fixed and stained. The number of micronuclei-containing cells per 2000 cells was counted in wells that showed at most $70 \%$ growth inhibition as determined by the MTT assay. Data were analyzed using the $\chi^{2}(\alpha=0.05$, degrees of freedom $=1$ ) test against DMSO controls.

Compound $\mathbf{1 1}$ did not cause DNA fragmentation in this test (Table 4).

\section{Cytotoxicity Evaluation Using MTT}

For every 96-well plate prepared above, a parallel 96-well plate was prepared to determine cytotoxicity, except that all volumes were halved. Survival estimation based on MTT reduction to formazan was modified from Mossman [14], and carried out at the time of harvesting.

The L5178Y cells were rinsed once then resuspended with $100 \mu$ FM10. To each well was then added $100 \mu$ of $0.5 \mathrm{mg} / \mathrm{ml} \mathrm{MTT}(5 \mathrm{mg} / \mathrm{ml} \mathrm{MTT}$ in PBS, diluted $10 \times$ in Dulbecco's modified Eagle's medium without phenol red), and the cells were incubated for 3 hours $\left(37^{\circ} \mathrm{C}, 5 \% \mathrm{CO}_{2}\right.$, $100 \%$ humidity). The medium was decanted, and the cells resuspended in acid isopropanol ( 1 volume $1 \mathrm{~N} \mathrm{HCl}$ to 23 volumes isopropanol) for 10 minutes with agitation. The plates were read in an ELISA plate reader $(550 \mathrm{~nm}$ absorbance wavelength, $620 \mathrm{~nm}$ reference wavelength).

The percent inhibition was determined relative to DMSO controls, and the $\mathrm{IC}_{50}$ determined by linear regression of $\mathrm{p}^{\prime}$ versus $\log$ concentration as done for the in vitro malaria test. ANOVA was done as described above.

Compound 11 was cytotoxic against L5178Y cells $\left(\mathrm{IC}_{50}\right.$ of $5.8 \mu \mathrm{M}$ for a 24 -hour exposure to the drug, without $\mathrm{S} 9$ activation). This $\mathrm{IC}_{50}$ is at least 10 times higher than that against malaria.

Compound 11 was clearly an active drug, combining in vitro antiparasitic activity with significant reduction in the number and size of schizonts in treated cultures and marked morphological alterations of the parasite. And it appears that the guanidine nucleus and the aliphatic chain are both important for maximum activity.

The ionic pocket in the guanidine nucleus might explain the molecule's biological activity. The guanidinium was found to interact with the fluoroborate anion in a bidentate ligating mode similar to that observed with carboxylates and phosphates [15]. The same kind of hydrogen-bond- 
mediated interaction is involved in substrate recognition at enzyme binding sites involving the guanidine-containing side chain of arginine residues, for example. In addition, the guanidinium has been tested in synthetic host receptors for phosphate- and carboxylate-containing host molecules [16].

A long aliphatic chain, on the other hand, appears to improve activity. These results support the suggestion of Overman et al. that a long chain might be important for binding to membranes, acting as a chaperone for the guanidino nucleus [17].

Other authors have suggested a role for polyamines. Putrescine linked to chloroquine, for example, was found to increase the drug's activity, perhaps by taking advantage of the increased permeability of the infected erythrocyte to polyamines [18]. In a similar approach, targeting choline transporters was shown by Wengelnik et al. to be effective, achieving cures in a primate model with as little as $0.01 \mathrm{mg} / \mathrm{kg}$ by intramuscular route and $4 \mathrm{mg} / \mathrm{kg}$ by oral route of a choline analogue, G25 [19].

The mechanism of action of compound $\mathbf{1 1}$ is not known, although ptilomycalin A was shown to inhibit $\mathrm{Na}^{+}, \mathrm{K}^{+}$, and $\mathrm{Ca}^{2+}$-ATPases $\left(\mathrm{IC}_{50}=2 \sim 10 \mu \mathrm{M}\right)$ by competitive inhibition at the ATP-binding site [20]. Crambescidin 816 was shown to specifically block L-type calcium channels (with possible consequences on calcium-dependent ATPases), with an $\mathrm{IC}_{50}$ of $0.15 \mathrm{nM}, 10000$ times smaller than the calcium channel blocker nifedipine [21].

In contrast, the antimalarial drug artemisinine appears to bind the plasmodial ATPase PfATP6, but no information on the activity of the compounds described here on artemisinin-resistant strains have been obtained [22].

Compound $\mathbf{1 1}$ itself might not be useful as a causal prophylactic. Its $\mathrm{IC}_{50}(490 \mathrm{nM})$ is not as low as that of chloroquine $(12 \sim 50 \mathrm{nM})$, artemisinin $(1 \sim 20 \mathrm{nM})$, halofantrine $(0.2 \sim 5 \mathrm{nM})$, and atovaquone $(0.2 \sim 2 \mathrm{nM})$. However, the uniqueness of the structure and the possibility of synthesizing analogues could make the molecule interesting as a lead compound.

Acknowledgements Marine samples were collected by R Sabal, Mindanao State University and PN Aliño and his group at UPMSI, and identified by MK Harper, University of Utah. ${ }^{1} \mathrm{H}-$ NMR spectroscopy was performed by $\mathrm{S}$ Mitchell and mass spectrometry by EM Rachlin, University of Utah.

This work was supported by grants from DOST-PCAMRD, Philippine government (GPC); French Embassy, Manila (JEL); NCDDG collaborative projects, NCI, US NIH (GPC and CMI); International Foundation for Science grant \#F1760 and UPMSI grants (GPC); EPSRC (GPB, CGM, DAT) and AstraZeneca (DAT).
References

1. Jares-Erijman EA, Sakai R, Rinehart KL. Crambescidins: new antiviral and cytotoxic compounds from the sponge Crambe crambe. J Org Chem 56: 5712-5715 (1991)

2. Black GP, Coles SJ, Hizi A, Howard-Jones AG, Hursthouse MB, McGown AT, Loya S, Moore CG, Murphy PJ, Smith NK, Walshe NDA. Synthesis and biological activity of analogues of ptilomycalin A. Tetrahedron Lett 42: 3377-3381 (2001)

3. Black GP, Murphy PJ, Thornhill A, Walshe NDA, Zanetti C. Synthesis of the left hand unit of batzelladine F: revision of the reported relative stereochemistry. Tetrahedron 55: 6547-6554 (1999)

4. Caukett P, Howard-Jones A, Murphy PJ, Thomas D. Synthesis of a novel C2 symmetric guanidine base. J Org Chem 64: 1039-1041 (1999)

5. Black GP, Murphy PJ, Walshe NDA. A short synthetic route to the tricyclic guanidinium core of the batzelladine alkaloids. Tetrahedron 54: 9481-9488 (1998)

6. Druilhe P, Gentilini M. Culture in vitro de Plasmodium falciparum: interêt et limites, méthodologie. Med Trop 42: 437-458 (1982)

7. Mirovsky P, Gay F, Bustos F, Mazier D, Gentilini M. Cloning of a fresh isolate of Plasmodium falciparum and drug sensitivity of the clones. Trans R Soc Trop Med Hyg 84: 511-515 (1989)

8. Finney DJ. Statistical Method in Bioassay, 3rd ed. Charles Griffin \& Company, Ltd., London (1978)

9. Schneider MD. Characteristics and cross-resistance patterns of chloroquine-resistant Plasmodium berghei infections in mice. Exp Parasitol 23: 22-50 (1968)

10. Lazaro JEH, Nitcheu J, Predicala RZ, Mangalindan GC, Nesslany F, Marzin D, Concepcion GP, Diquet B. Heptyl prodigiosin, a bacterial metabolite, is antimalarial in vivo and non-mutagenic in vitro. J Nat Toxins 11: 366-377 (2002)

11. Basco LK, Ringwald P, Franetich JF, Mazier D. Assessment of pyronaridine activity in vivo and in vitro against the hepatic stages of malaria in laboratory mice. Trans R Soc Trop Med Hyg 93: 651-652 (1999)

12. Mahmoudi N, Ciceron L, Franetich JF, Farhati K, Silvie O, Eling W, Sauerwein R, Danis M, Mazier D, Derouin F. In vitro activities of 25 quinolones and fluoroquinolones against liver and blood stage Plasmodium spp. Antimicrob Agents Chemother 47: 2636-2639 (2003)

13. Nesslany F, Marzin D. A micromethod for the in vitro micronucleus assay. Mutagenesis 14: 403-410 (1999)

14. Mosmann T. Rapid colorimetric assay for cellular growth and survival, application to proliferion and cytotoxicity assays. J Immunol Methods 65: 55-63 (1993)

15. Murphy PJ, Williams HL, Hibbs DE, Hursthouse MB, Malik KMA. Crystallographic evidence for the proposed host behaviour of ptilomycalin A. J Chem Soc Chem Commun 
1996: 445-447 (1996)

16. Schmidtchen FP, Berger M. Artificial organic host molecules for anions. Chem Rev 97: 1609-1646 (1997)

17. Overman LE, Rabinowitz MH, Renhowe PA. Enantioselective total synthesis of (-)-ptilomycalin A. J Am Chem Soc 117: 2657-2658 (1995)

18. Singh S, Puri SK, Singh SK, Srivastava R, Gupta RC, Pandey VC. Characterization of simian malarial parasite (Plasmodium knowlesi)-induced putrescine transport in rhesus monkey erythrocytes. A novel putrescine conjugate arrests in vitro growth of simian malarial parasite (Plasmodium knowlesi) and cures multidrug resistant murine malaria (Plasmodium yoelii) infection in vivo. J Biol Chem 272(21): 13506-13511 (1997)

19. Wengelnik K, Vidal V, Ancelin ML, Cathiard AM, Morgat JL, Kocken CH, Calas M, Herrera S, Thomas AW, Vial HJ.
A class of potent antimalarials and their specific accumulation in infected erythrocytes. Science 295: 1311-1314 (2002)

20. Ohizumi Y, Sasaki S, Kusumi T, Ohtani II. Ptilomycalin A, a novel $\mathrm{Na}^{+}, \mathrm{K}^{+}$,- or $\mathrm{Ca}^{2+}$-ATPase inhibitor, competitively interacts with ATP at its binding site. Eur J Pharmacol 310: 95-98 (1996)

21. Berlinck RGS, Braekman JC, Daloze D, Bruno I, Riccion R, Ferri S, Spampinato S, Speroni E. Polycyclic guanidine alkaloids from the marine sponge Crambe crambe and $\mathrm{Ca}^{++}$ channel blocker activity of crambescidin 816. J Nat Prod 56: 1007-1015 (1993)

22. Eckstein-Ludwig U, Webb RJ, Van Goethem ID, East JM, Lee AG, Kimura M, O’Neill PM, Bray PG, Ward SA, Krishna S. Artemisinins target the SERCA of Plasmodium falciparum. Nature 424: 887-889 (2003) 